\title{
OCCURENCE OF PROTOZOAN FROM THE GENUS Cryptosporidium Spp. IN CATTLE RAISED IN PROPERTIES OF THE RURAL ZONE IN THE COUNTY OF BOM JESUS, PIAUÍ
}

[Ocorrência de protozoários do gênero Cryptosporidium spp. em bovinos criados em propriedades da zona rural do município de Bom Jesus, Piaui]

Ronaldo do Ó Santos ${ }^{1}$, Marcelo Richelly Alves de Oliveira ${ }^{2 *}$, Carlos Syllas Monteiro Luz ${ }^{2}$, Bueno da Silva Abreu $^{3}$, Severino Cavalcante de Sousa Júnior ${ }^{4}$, Karina Rodrigues dos Santos ${ }^{4}$

\footnotetext{
${ }^{1}$ Universidade Federal do Piauí (UFPI), Bom Jesus, PI, Brasil.

${ }^{2}$ Universidade Federal do Piauí (UFPI), Teresina, PI, Brasil.

${ }^{3}$ Universidade Federal Rural (UFRPE), Recife, PE, Brasil.

${ }^{4}$ Universidade Federal do Piauí (UFPI), Parnaíba, PI, Brasil.
}

RESUMO - O objetivo com esta pesquisa foi verificar a ocorrência de coccídios do gênero Cryptosporidium em amostras fecais de bovinos criados na zona rural da cidade de Bom Jesus, estado do Piauí. Para isso, amostras fecais foram colhidas de 50 bovinos de sexo, idade e raças variadas de três propriedades. Para análise dos oocistos de Cryptosporidium spp. foram utilizadas as técnicas de Ritchie e coloração de Ziehl-Neelsen. Foram identificados oocistos do gênero Cryptosporidium nas fezes de $60 \%$ dos animais avaliados. De 30 animais, cinco apresentavam fezes com consistência diarreica, enquanto 25 eram assintomáticos. Assim, foi observada elevada ocorrência de infecções por protozoários do gênero Cryptosporidium spp. nos rebanhos bovinos avaliados neste estudo.

Palavras-Chave: criptosporidiose; protozoário; ruminantes; zoonose.

\begin{abstract}
The objective of this research was to verify the occurrence of coccidia from the Cryptosporidium genus in fecal samples of cattle raised in the rural zone in the county of Bom jesus, state of Piaui. To accomplish this, fecal samples were taken of 50 bovine from mixed gender, age and breed belonging to three properties. For analysis of Cryptosporidium spp. staining techniques from Ritchie and Ziehl-Neelsen were used. Oocysts from the genus Cryptosporidium were identified in the stools of $60 \%$ of evaluated animals. From a total of 30 animals, five showed stool with diarrheal consistency, while 25 were asymptomatic. Thus, it was observed a high incidence of infections by protozoa of the genus Cryptosporidium spp. in cattle herds in this study.
\end{abstract}

Keywords: Cryptosporidiosis; protozoan; ruminants; zoonosis.

\footnotetext{
* Autor para correspondência. E-mail: marcelo-zootec@ hotmail.com Recebido: 18 de agosto de 2016.

Aceito para publicação: 21 de novembro de 2016.
} 


\section{INTRODUCTION}

Cryptosporidiosis may be defined as a global parasitic zoonosis. It is a diarrheal disease caused by parasites from the genus Cryptosporidium (Rodrigues et al., 2016), an obligate intracellular parasite that has endogenous development, being able to infect the microvilli epithelial cells of the intestinal and / or bronchial trees and infects vertebrate species (Imre; Dărăbuș, 2011; Bresciani et al., 2013). These parasites are responsible for the aqueous diarrhea syndrome, as well as for abdominal pain, dehydration, weight loos, growth delay and in many cases animal decease (Galvão et al., 2012; Wang et al., 2011), and considered as producing a high risk infection for newborn and immunosuppressed individuals, thus causing significant economic losses.

This parasite may infect many species of domestic and wild animals, as well as reptiles, aquatic species and human beings (Vargas Júnior et al., 2014).

These are not a species-specific parasites, thus transmission between different animal species to humans is possible. Among the 30 named species, nine species have zoonotic potential (Slapeta, 2013). The most prevalent species in humans are: Cryptosporidium hominis, Cryptosporidium parvum, Cryptosporidium meleagridis, Cryptosporidium cuniculus and seldom, Cryptosporidium muris (Gatei et al., 2006) Cryptosporidium suis (Leoni et al., 2006), Cryptosporidium ubiquitum (ONG et al., 2002), Cryptosporidium felis and Cryptosporidium canis (Xiao, 2010; Smith; Nichols, 2010; Chalmers; Katzer, 2013; Slapeta, 2013; Galván et al., 2014).

The Oocysts, the infecting form of the parasite, are released in the feces and may remain viable for months, being the fecal-oral the main transmission path. Once ingested by the host, the oocyst are replicated in the inside of the epithelium and by means of sequential reproductive cycles the population progresses resulting in the release of thousands of oocysts per day in the feces. The transmission is linked to water and food intake as well as contact with infected animals and/or humans (Huber et al., 2007; Smith et al., 2007; Rossi et al., 2014).

Cryptosporidiosis is among the three causes in the etiology of diarrheas, responsible for economic losses due to animal deaths and by compromising the development of infected animals (Vargas Júnior et al., 2014). Among domesticated animals, ruminants, are frequently affected, especially young animals like goats (Brito et al., 2014), buffalo calves (Aquino et al., 2015), lambs (Zucatto et al., 2015).

Bovines are the most studied group of domestic animals, with morbidity rates caused by $C$. parvum varying from $5 \%$ to $11 \%$ (Lima et al., 2013), especially in younger animals, a value considered high when associated to other infectious agents, weakness due to nutritional status and immunosuppression of calves (Couto; Bomfim, 2012; Fayer et al., 2010; Thomas et al., 2007).

Bovines may be infected basically by four Cryptosporidium species: C. parvum, C. bovis, $C$. ryanae and $C$. andersoni (Fayer; Santín; Dargatz, 2010). From these, only C. parvum has zoonotic importance and occurs in ruminants, humans and mice (Sônia, 2012).

To evidence the presence of such parasites in the cattle feces is relevant, once infection of this and other animal species and humans constitutes a public health problem.

Due to the significance of this disease as a zoonotic parasitic infection, the objective of this work was to verify the occurrence of Coccidians form the genus Cryptosporidium in fecal samples from cattle.

\section{MATERIAL AND METHODS}

Fifty bovine animals from several breed properly marked in the county of Bom Jesus, state of Piaui, with rings or collars were used in this experiment. The animals belonged to herds from three different farms, randomly chosen. Animals were randomly selected with different ages and sex.

Fecal samples were individually obtained from the 50 selected animals. The samples were obtained directly from the rectum ampulla.

\section{Parasitological analysis of fecal samples}

To analyze the concentration of Cryptosporidium spp. oocysts modified methods from Ritchie (1948) and from Ziehl-Neelsen (Henriksen \& Pohlenz, 1981) were used for oocyst's staining. Two slides per sample were obtained and observed under light microscope with an immersion objective of $100 \mathrm{x}$ magnification. Samples showing spherical elements with four sporozoites stained in pink were considered as positive results for the presence of Cryptosporidium (Figrure 1).

\section{Method of Formalin - Ether - Ritchie (1948)}

In this method we used $1 \mathrm{~g}$ of feces in $4 \mathrm{ml}$ buffered saline solution. The solution was filtered in gauze and transferred to $6 \mathrm{ml}$ tubes, which were completed 
with saline solution up to the edge. Tubes were centrifuged at $500 \mathrm{rpm}$ for 8 minutes, in a Sislab/Tister centrifuge, the supernatant was eliminated and tubes completed again with buffered saline solution before centrifuged at $500 \mathrm{rpm}$ for 8 minutes. The supernatant was disposed and $3 \mathrm{ml}$ of refrigerated Ether were added before vigorous homogenization of each tube for 30 seconds, then tubes were finally centrifuged at $500 \mathrm{rpm}$ for 8 minutes.

For layers resulted from this procedure: solvent, fecal remains, saline solution and sediments containing oocysts of Cryptosporidium, the supernatant was again disposed and fine smears were prepared with the remaining fecal residue from the bottom of the tubes. Smears were air-dried at room temperature and fixed in methanol for 3 minutes, similar to the procedure described by Cosendey et al. (2008).

Method of carbol-fuchsine staining or ZiehlNeelsen modified staining (Henriksen \& Pohlenz, 1981)

To stain the smears a carbol fuchsine solution was used for 20 minutes, followed by washing in running tap water, saline solution and fast wash with acid alcohol until the excess of dye was removed and then washed again in running tap water, before finally dried at room temperature.
Data were stored and analyzed with the aid of the software SAS, to check residual homoscedasticity, and from this we created a table with the number of animals, sex, age and the test results for further analysis of the data using the software Excel 2010, where each variable was crossed with the other aiming a maximum efficiency of results. Calculation of absolute and relative frequencies were performed, and the resulting information were analyzed using graphs and tables.

\section{RESULTS AND DISCUSION}

Oocysts from the genus Cryptosporidium were identified in the feces of $60 \%$ of the evaluated animals. Results for the diagnosis of Cryptosporidium presence in the evaluated farms are shown in Table 1 and Figure 1.

Table 1. Prevalence of Cryptosporidium oocysts in fecal samples from cattle, analyzed by modified methods from Ziehl-Neelsen and Ritchie.

\begin{tabular}{cccc}
\hline \multirow{2}{*}{ Farm } & \multicolumn{2}{c}{ Sample } & \multirow{2}{*}{ Total } \\
\cline { 2 - 3 } & Positive & Negative & \\
\hline 1 & 16 & 05 & 21 \\
2 & 08 & 04 & 12 \\
3 & 06 & 11 & 17 \\
\hline Total & 30 & 20 & 50 \\
\hline
\end{tabular}
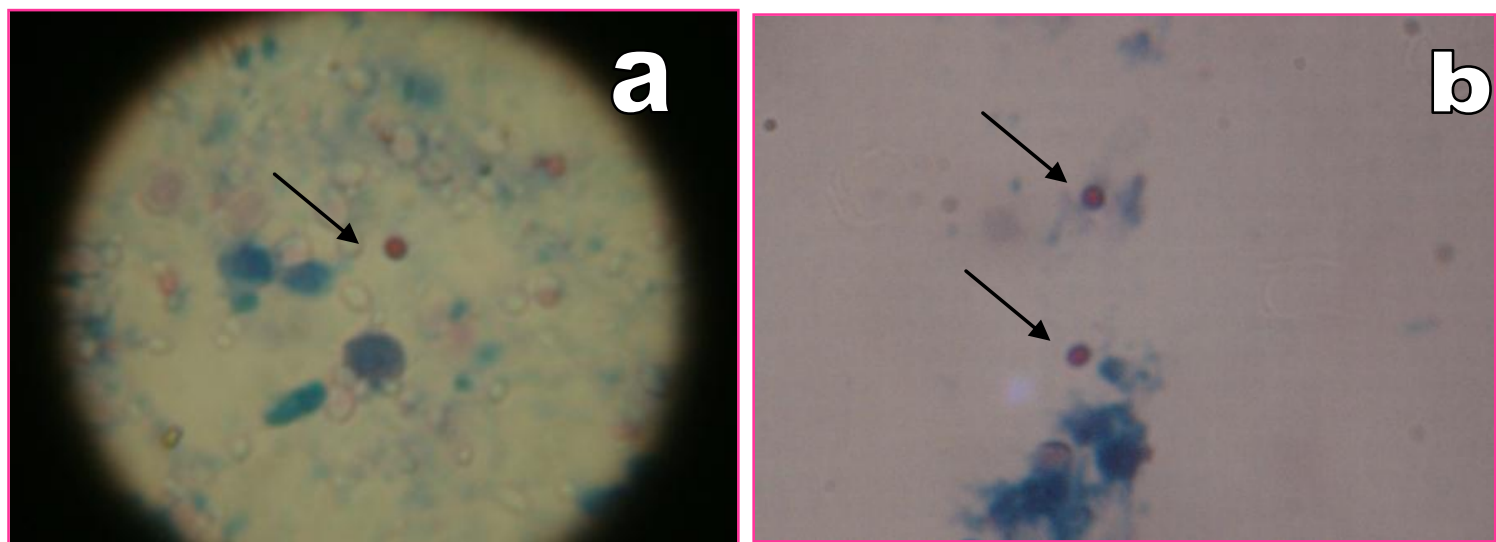

Figure 1. Oocyst of protozoa from the genus Cryptosporidium found in stool samples examined by the Ziehl Neelsen modified technique. Figures (a) and (b) show the presence oocysts of the genus Cryptosporidium (1000x). Source: author's collection.

All the three farms comprehended in the present study showed at least one animal infected by the parasite. This result may be justifiable due to the infection intensity in adult individuals of the herd. The fact of Cryptosporidium oocysts are shed in the feces of the host already sporulated facilitates the infection of other animals in the farm and contaminate surface waters of rivers for up to six months at temperatures between $0^{\circ}$ and $20^{\circ} \mathrm{C}$ (Bresciani et al., 2013).
In the county of Campos dos Goytacazes, state of Rio de Janeiro, oocysts of Cryptosporidium spp. were found in $100 \%$ of the analyzed calves, using the Ziehl-Neelsen modified method (Almeida et al., 2008). Teixeira et al. (2011) also reported $100 \%$ of the animals parasitized by this protozoan in a study in the state of São Paulo.

In the present study, it was possible to observe a difference between the infection levels of the farms studied, this may be related with the period of the 
year when the samples and animal examination were performed. In farm 01, examinations were carried out during December, a period with high concentration of rain falls and high humidity, a set of favorable conditions for the parasite. In farms 02 and 03, sample collection and animal examination were accomplished in March and April, respectively, periods where the rain concentration and humidity were low (Figure 2).

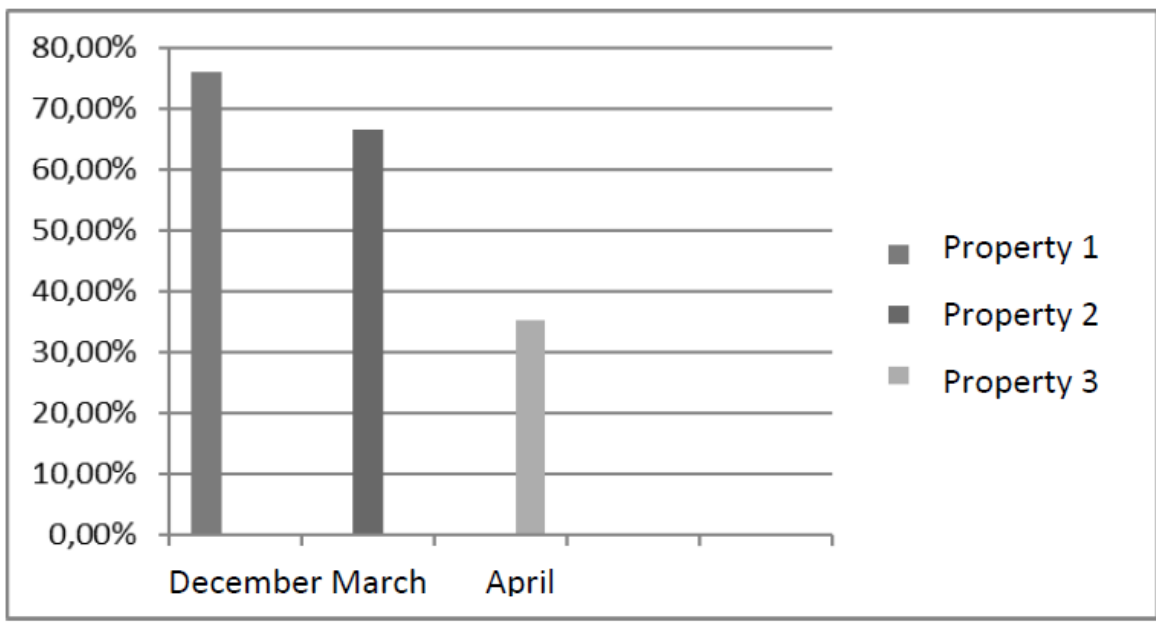

Figure 2. Percentage of infection in the farms, according to the period of the year used for sample collection and analysis of the animal feces.

According Bresciani et al. (2013) other factors besides host age may contribute for the predisposing of Cryptosporidium spp., as the association with other parasites, which immunosuppresses the host, facilitating the infections by Cryptosporidium spp. oocysts.

Regarding the percentage of calves infected in the present study $(60 \%)$, it is comparable to the percentages reported by Fayer, Santín; Xiao (2005) and Thompson et al. (2007), which observed a variation from $14.0 \%$ to $57.8 \%$ in the prevalence of infection by parasites from the genus Cryptosporidium in various countries like Brazil, Spain and United States of America.

In adult animals the percentage observed was of $58.06 \%$, this percentage is, however, lower than that reported by Lorenzo; Ares-Mazas and Villacorta (1993), which found $71.75 \%$ of positive adult animals for Cryptosporidium. According Yoshiuchi et al. (2010) this result may be explained due to the fact that in immunocompetent animals the infection by Cryptosporidium spp. becomes self-limiting, being most common the detection in calves, while in adult individuals such infection may have no obvious symptoms like diarrhea.

A correlation between levels of infection by Cryptosporidium and the frequency of the main symptom, diarrhea, was performed using the fecal samples from bovines that resulted positive for the parasite. From a total of 30 individuals, 05 showed feces with consistence of diarrhea, while 25 were asymptomatic carriers (Figure 3 ).

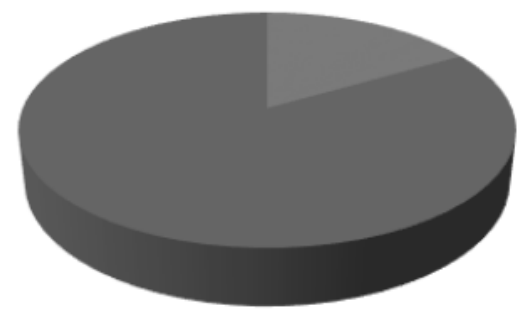

1을 Diarrheic

2№ Diarrheic

Figure 3. Percentage of animals with positive result for Cryptosporidium, with presence and absence of diarrhea. 
The confirmation that Cryptosporidium is associated with cattle diarrhea (Fayer et al., 2006), certainly support its significance, together with other infectious agents within the etiological complex of cattle diarrheas in Brazil. However, it is probable that numerous factors as the presence of pathogenic bacteria from the bowel, various protozoa and virus, different characteristics related to the environment and the immunological status of the individuals may be associated during the development of intestinal inflammations in bovines, not resulting, in the majority of the cases, from the effect exerted from a single pathogenic agent (Feitosa et al., 2008).

It is possible to determine that the high number of asymptomatic animals and the lack of knowledge concerning this protozoan as causing agent of diarrhea by the farmers in the region, results in an elevated dissemination without a proper control for this agent. Extensive research concerning the etiology of diarrheas in bovines must be completed considering the fact that Cryptosporidium spp. is one of the main agents causing intestinal infections.

The implementation of efficient management practices is still the best method to avoid and prevent farms from infections by Cryptosporidium spp.

\section{CONCLUSION}

We can infer that high occurrence of Cryptosporidium spp. in fecal samples from cattle of the three properties in the county of Bom Jesus, state of Piauí were observed.

\section{REFERENCES}

ALMEIDA, A. J. et al. Risco relativo da infecção por parasitos do gênero Cryptosporidium em bezerros bovinos no norte do estado do Rio de Janeiro, Brasil. Revista Brasileira de Parasitologia Veterinária, v. 17, n. 1, p. 243-248, 2008.

AQUINO, M. C. C. et al. First Molecular Characterization of Cryptosporidium spp. Infecting Buffalo Calves in Brazil. The Journal of Eukaryotic Microbiology, v.62, n.5, p.657-661, 2015.

BRESCIANI, K. D. S. et al. Criptosporidiose em animais domésticos: aspectos epidemiológicos. Semina: Ciências Agrárias, v. 34, n. 5, p. 2387-2402, 2013.

BRITO, R. L. L. et al. Ocorrência da infecção por Cryptosporidium spp. em cabritos (Capra hircus). Pesquisa Veterinária Brasileira, v.34, n.8, p. 728-732, 2014

CHALMERS, R. M.; KATZER, F. Looking for Cryptosporidium: the application of advances in detection and diagnosis. Trends in Parasitology, Oxford, v. 29, n. 5, p. 237$251,2013$.

COSENDEY, R. I. J. Freqüência de oocistos de coccídios do gênero" Cryptosporidium" em ovinos no estado do Rio de Janeiro. Revista Brasileira de Saúde e Produção Animal, v. 9, n. 4, 2008 .
COUTO, M. C. M.; BOMFIM, T. C. B. Espécies de Cryptosporidium que infectam bovinos: características etiológicas e epidemiológicas. Veterinária Notícias, v. 18, n. 2, p. $94-109,2013$

FAYER, R.; SANTÍN, M.; XIAO, L. Cryptosporidium bovis $\mathrm{n}$. sp (Apicomplexa: Cryptosporidiidae) from cattle (Bos taurus). Journal of Parasitology, v. 91, n. 3, p. 624-629, 2005.

FAYER, R. et al. Detection of Cryptosporidium felis and Giardia duodenalis Assemblage $\mathrm{F}$ in a cat colony. Veterinary Parasitology, v. 140, n. 1, p. 44-53, 2006.

FAYER, R. et al. Species of Cryptosporidium detected in weaned cattle on cow-calf operations in the United States. Veterinary Parasitology, v. 170, n. 3, p. 187-192, 2010.

FAYER, R.; SANTÍN, M.; DARGATZ, D. Species of Cryptosporidium detected in weaned cattle on cow-calf operations in the United States. Veterinary Parasitology, v. 170 , n. 3-4, p. 187-192, 2010.

FEITOSA, F. L. F. et al. Importância de Cryptosporidium spp. como causa de diarréia em bezerros. Pesquisa Veterinária Brasileira, v. 28, n. 10, p. 452-456, 2008.

GALVÁN, A. L. et al. A year-long study of Cryptosporidium species and subtypes in recreational, drinking and wastewater from the central area of Spain. Science of The Total Environment. v. 468-469, p. 368-375, 2014

GALVÃO, A. L. B. et al. Importância da criptosporidiose como zoonose. Archives of Veterinary Science, v. 17, n. 2, p. 18-28, 2012.

GATEI, W. et al. Cryptosporidiosis: prevalence, genotype analysis, and symptoms associated with infections in children in Kenya. American Journal of Tropical Medicine and Hygiene, v. 75 , n. 1, p. 78-82, 2006.

HENRIKSEN, S.; POHLENZ, I. J. Staining of cryptosporidia by a modified Zielh-Neelsen technique. Acta Veterinaria Scandinavica, v. 22, n. 3-4, p. 594-596, 1981.

HUBER, F. et al. Genotypic characterization and phylogenetic analysis of Cryptosporidium sp. from domestic animals in Brazil. Veterinary Parasitology, v. 150, n. 1, p. 65-74, 2007.

IMRE, K.; DĂRĂBUȘ, G. Distribution of Cryptosporidium species, genotypes and $C$. parvum subtypes in cattle in European countries. Scientia Parasitologica, v12, n.1, p. 1-9, 2011.

LEONI, F. et al. Genetic analysis of Cryptosporidium from 2414 humans with diarrhoea in England between 1985 and 2000. Journal of Medical Microbiology, v. 55, n. 6, p. 703-707, 2006.

LIMA, R. C. A. et al. Caracterização molecular de Cryptosporidium spp. em bezerros (Bos taurus e Bos indicus) no município de Formiga, Minas Gerais - Brasil. Semina. Ciências Agrárias (Online), v. 34, p. 3747, 2013.

LORENZO M. J.; ARES-MAZAS E.; VILLACORTA M. M. Detection of oocysts and $\mathrm{IgG}$ antibodies to Cryptosporidium parvum in asymptomatic adult cattle. Veterinary Parasitology. v. 47 , n. $1-2$, p. 9-15. 1993.

ONG, C. S. L. et al. Novel Cryptosporidium genotypes in sporadic cryptosporidiosis cases: first report of human infections with a cervine genotype. Emerging Infectious Diseases, v. 8, n. 3, p. 263-268, 2002.

RITCHIE, L. S. An ether sedimentation technique for routine stool examinations. Bulletin United States Army. Medical Department, v. 8, n. 4, p. 326, 1948. 
RODRIGUES, R. D. et al. Comparação da eficiência das colorações de Ziehl-Neelsen modificado e Safranina modificada na detecção de oocistos de Cryptosporidium spp. (Eucoccidiorida, Cryptosporidiidae) a partir de amostras fecais de bezerros de 0 a 3 meses. Ciência Animal Brasileira, v. 17, n. 1, p. 119-125, 2016.

ROSSI, G. A. M. et al. Zoonoses parasitárias veiculadas por alimentos de origem animal: revisão sobre a situação no Brasil. Arquivos do Instituto Biológico, v. 81, n. 3, p. 290-298, 2014.

SLAPETA, J. Cryptosporidiosis and Cryptosporidium species in animals and humans: A thirty colour rainbow? International journal for parasitology, v. 43, n. 12-13, p. 957-970, 2013.

SMITH, H. V. et al. Cryptosporidium and Giardia as foodborne zoonoses. Veterinary Parasitology, v. 149, p. 29-40, 2007.

SMITH, H. V.; NICHOLS, R. A.B. Cryptosporidium: Detection in water and food. Experimental Parasitology, v. 124, n. 1, p. $61-79,2010$

SÔNIA, F. O. S. Avaliação de técnicas imunológicas e moleculares para detecção de oocistos de Cryptosporidium spp. em águas tratadas no município de Goiânia-Goiás-Brasil. Revista de Patologia Tropical, v. 41, n. 3, p. 375-376, 2012.

TEIXEIRA, W. F. P. et al. Diagnóstico de criptosporidiose em amostras fecais de bezerros por imunofluorescência direta $\mathrm{e}$ microscopia de contraste de fase. Ciência Rural, v. 41, n. 6, p. 1057-1062, 2011

THOMPSON, H. P. et al. Genotypes and subtypes of Cryptosporidium spp. in neonatal calves in Northern Ireland. Parasitology Research, v. 100, n. 3, p. 619-624, 2007.

VARGAS JÚNIOR, S. F. et al. Surto de criptosporidiose em bezerros no Sul do Rio Grande do Sul. Pesquisa Veterinária Brasileira, v. 34, n. 8, p. 749-752, 2014.

WANG, R. et al. Characteristics of Cryptosporidium transmission in pre weaned dairy cattle in Henan, China. Journal of Clinical Microbiology, v. 49, n. 3, p. 1077-1082, 2011.

XIAO, L. Molecular epidemiology of cryptosporidiosis: An update. Experimental Parasitology, v. 124, n. 1, p. 80-89, 2010.

YOSHIUCHI, R. et al. Survey and molecular characterization of Cryptosporidium and Giardia spp. in owned companion animal, dogs and cats, in Japan. Veterinary Parasitology, Amsterdam, v. 174, n. 3-4, p. 313-316, 2010.

ZUCATTO, A. S. et al. Molecular characterisation of Cryptosporidium spp. in lambs in the South Central region of the State of São Paulo. Arquivo Brasileiro de Medicina Veterinária e Zootecnia, v.67, p.441 - 446, 2015. 